\title{
Front Matter: Volume 7238
}

, "Front Matter: Volume 7238," Proc. SPIE 7238, The Engineering Reality of Virtual Reality 2009, 723801 (4 February 2009); doi: 10.1117/12.824165

SPIE Event: IS\&T/SPIE Electronic Imaging, 2009, San Jose, California, United SPIE. States 


\title{
PROCEEDINGS \\ IS\&T/SPIE \\ Electronio \\ Imeging \\ Science and Technology
}

\section{The Engineering Reality of Virtual Reality 2009}

\author{
Ian E. McDowall \\ Margaret Dolinsky \\ Editors
}

22 January 2009

San Jose, California, United States

Sponsored and Published by

IS\&T-The Society for Imaging Science and Technology

SPIE 
The papers included in this volume were part of the technical conference cited on the cover and title page. Papers were selected and subject to review by the editors and conference program committee. Some conference presentations may not be available for publication. The papers published in these proceedings reflect the work and thoughts of the authors and are published herein as submitted. The publishers are not responsible for the validity of the information or for any outcomes resulting from reliance thereon.

Please use the following format to cite material from this book:

Author(s), "Title of Paper," in The Engineering Reality of Virtual Reality 2009, edited by lan E. McDowall, Margaret Dolinsky, Proceedings of SPIE-IS\&T Electronic Imaging, SPIE Vol. 7238, Article CID Number (2009).

ISSN 0277-786X

ISBN 9780819474889

Copublished by

SPIE

P.O. Box 10, Bellingham, Washington 98227-0010 USA

Telephone +1 3606763290 (Pacific Time) · Fax +1 3606471445

SPIE.org

and

IS\&T-The Society for Imaging Science and Technology

7003 Kilworth Lane, Springfield, Virginia, 22151 USA

Telephone +1 7036429090 (Eastern Time) · Fax +1 7036429094

imaging.org

Copyright (C) 2009, Society of Photo-Optical Instrumentation Engineers and The Society for Imaging Science and Technology.

Copying of material in this book for internal or personal use, or for the internal or personal use of specific clients, beyond the fair use provisions granted by the U.S. Copyright Law is authorized by the publishers subject to payment of copying fees. The Transactional Reporting Service base fee for this volume is $\$ 18.00$ per article (or portion thereof), which should be paid directly to the Copyright Clearance Center (CCC), 222 Rosewood Drive, Danvers, MA 01923. Payment may also be made electronically through CCC Online at copyright.com. Other copying for republication, resale, advertising or promotion, or any form of systematic or multiple reproduction of any material in this book is prohibited except with permission in writing from the publisher. The CCC fee code is 0277-786X/09/\$18.00.

Printed in the United States of America.

Paper Numbering: Proceedings of SPIE follow an e-First publication model, with papers published first online and then in print and on CD-ROM. Papers are published as they are submitted and meet publication criteria. A unique, consistent, permanent citation identifier (CID) number is assigned to each article at the time of the first publication. Utilization of CIDs allows articles to be fully citable as soon they are published online, and connects the same identifier to all online, print, and electronic versions of the publication. SPIE uses a six-digit CID article numbering system in which:

- The first four digits correspond to the SPIE volume number.

- The last two digits indicate publication order within the volume using a Base 36 numbering system employing both numerals and letters. These two-number sets start with 00, 01, 02, 03, 04, 05, 06, 07, $08,09,0 \mathrm{~A}, \mathrm{OB} \ldots \mathrm{OZ}$, followed by 10-1Z, 20-2Z, etc.

The CID number appears on each page of the manuscript. The complete citation is used on the first page, and an abbreviated version on subsequent pages. Numbers in the index correspond to the last two digits of the six-digit CID number. 


\title{
Contents
}

\author{
$\checkmark$ Conference Committee \\ vii Introduction
}

\section{SESSION 1 DELIGHTFUL DEVICES AND AUGMENTING REALITY}

723802 Model-based registration of multi-rigid-body for augmented reality [7238-01]

S. Ikeda, H. Hori, M. Imura, Y. Manabe, K. Chihara, Nara Institute of Science and Technology (Japan)

723803 Automatic human detecting and tracking using stereo vision technique [7238-02] Y. Wang, G. Morrison, Smart Technologies ULC (Canada)

723804 Real-time geometric registration using feature landmark database for augmented reality applications [7238-03]

T. Taketomi, T. Sato, N. Yokoya, Nara Institute of Science and Technology (Japan)

\section{SESSION 2 EVOKING ENVIRONMENTS THROUGH ARTFUL DISTINCTIVENESS}

723805 A strategic map for high-impact virtual experience design [7238-05]

H. Faste, M. Bergamasco, Scuola Superiore S. Anna (Italy)

723806 Computer graphics synthesis for inferring artist studio practice: an application to Diego Velázquez's Las Meninas [7238-06]

D. G. Stork, Ricoh Innovations (United States); Y. Furuichi, Consultant (Japan)

723807 Becoming Dragon: a mixed reality durational performance in Second life [7238-07] M. Cárdenas, C. Head, T. Margolis, K. Greco, Univ. of California, San Diego (United States)

723808 Dots and dashes: art, virtual reality, and the telegraph [7238-08]

S. Ruzanka, Univ. of Hartford (United States); B. Chang, Art Institute of Chicago (United States)

\section{SESSION 3 FEELING AWARE: VR AS EXPERIENCE}

7238 OC Re-entry: online virtual worlds as a healing space for veterans [7238-12]

J. F. Morie, Univ. of Southern California (United States)

7238 OD DJ Sim: a virtual reality DJ simulation game [7238-13]

K. Y. Tang, M. H. Loke, C. L. Chin, G. G. Chua, J. H. Chong, C. Manders, I. R. Khan, M. Yuan,

F. Farbiz, A*STAR Institute for Infocomm Research (Singapore) 
7238 OF Interactive exploration of coastal restoration modeling in virtual environments [7238-15] A. Gerndt, German Aerospace Ctr. (DLR) (Germany); R. Miller, C. H. Fenstermaker \& Associates, Inc. (United States); S. Su, Louisiana Immersive Technologies Enterprise (United States); E. Meselhe, Univ. of Louisiana at Lafayette (United States); C. Cruz-Neira, Louisiana Immersive Technologies Enterprise (United States)

7238 OG Forensic aerial photography: projected 3-D exhibits facilitating rapid environmental justice [7238-16]

R. A. Pope, Waterstone Environmental, Inc. (United States)

$7238 \mathrm{OH} \quad$ Virtual hydrology observatory: an immersive visualization of hydrology modeling [7238-17] S. Su, C. Cruz-Neira, Louisiana Immersive Technologies Enterprise (United States); E. Habib, Univ. of Louisiana at Lafayette (United States); A. Gerndt, German Aerospace Ctr. (DLR) (Germany)

7238 ol Sensate abstraction: hybrid strategies for multi-dimensional data in expressive virtual reality contexts [7238-18]

R. West, Univ. of California, Los Angeles (United States); J. Gossmann, T. Margolis, J. P. Schulze, Univ. of California, San Diego (United States); J. P. Lewis, Weta Digital Ltd. (New Zealand); B. Hackbarth, I. Mostafavi, Univ. of California, San Diego (United States)

Author Index 


\title{
Conference Committee
}

\author{
Symposium Chair \\ Nitin Sampat, Rochester Institute of Technology (United States) \\ Symposium Cochair \\ Jan P. Allebach, Purdue University (United States) \\ Conference Chairs
}

Ian E. McDowall, Fakespace Laboratories, Inc. (United States)

Margaret Dolinsky, Indiana University (United States)

Session Chairs

1 Delightful Devices and Augmenting Reality

Ian E. McDowall, Fakespace Laboratories, Inc. (United States)

2 Evoking Environments through Artful Distinctiveness

Margaret Dolinsky, Indiana University (United States)

3 Feeling Aware: VR as Experience

Margaret Dolinsky, Indiana University (United States)

4 Interactive Science and Virtual Observation

Ian E. McDowall, Fakespace Laboratories, Inc. (United States) 
Downloaded From: https://www.spiedigitallibrary.org/conference-proceedings-of-spie on 26 Apr 2023

Terms of Use: https://www.spiedigitallibrary.org/terms-of-use 


\section{Introduction}

This year's conference collected a wide range of papers. The day started with several papers addressing the need to track things in VR spaces. Two papers from Japan illustrated the advances in camera based tracking by extracting features. The paper presented by Takafumi Taketomi illustrated an optimization of an algorithm which had been presented at a prior conference and showed tracking and registration in an outside environment. The third paper in that group addressed the problem of tracking a person's head with a stereo pair of monochrome cameras to ease presentation in front of a projector.

Haakon Faste, a PhD student from PERCRO, got the next session off to an interesting start by presenting his approach to structuring one's thinking about compelling virtual experiences and how to organize virtual experience design based on what he categorized as technocultural conditions. We look forward to seeing some of these aspects realized in the coming years. David Stork illustrated some of the computer graphics and VR simulations being undertaken to better understand the use of lighting by painters such as Vermeer and Velazquez in their artwork of the mid 1600's.

Micha Cardenas from UCSD followed and explored the themes of self image and body image. These themes were explored in the context of spending two weeks (365 hours) immersed in Second Life. Using head tracking and a head mounted display, Cardenas engaged with the world of Second Life by intersecting the boundaries between virtual world and real life in a public performance.

Silvia Ruzanka and Ben Chang explored the parallels in public perception during the introduction of the telegraph with that of the internet today. Interesting parallels also emerged in the way in which people interacted with time and space using the medium of the telegraph. Just as Cardenas noted that people in Second Life interact in sometimes more personal ways than they would in the real world, Chang and Ruzanka explored how relationships are affected in the context of the telegraph. A VR piece was created to reflect these explorations.

Isil Demir from Sabanci University reconfigured Spanish painter Joan Miro's concept of four dimensional painting in a project to design an avatar and control certain aspects of the avatar in Second Life using EEG recordings. Another presentation from singapore demonstrated interaction using tracked hand gestures to control a game interface for "scratching" as a virtual DJ.

Jackie Morie from ICT at USC presented her insights into how veterans of the recent conflicts in Iraq and Afghanistan react to certain spaces and places in Second Life and discussed her work to create a healing space in Second Life for these veterans. A ski lodge atmosphere has been modeled; creating an inviting 
common room for veterans. These veterans, who may have served in the same unit but live in different parts of the country, can now connect "in person" and receive services to assist in integration back into mainstream society.

Two papers then explored hydrological modeling along the coast being done at the LITE facility at the University of Louisiana at Lafayette. These data sets are modeled using collected data sets and satellite imaging. A collaborating researcher from the German Aerospace Center showed how these data sets are registered and rendered on the stereo displays.

Also in the environmental area, we learned from Robert Pope about the ways in which aerial photography is used in litigation to create virtual models of the evolution of various environmental impacts. These models are used to gain insights into historical intent and to guide ground survey crews on what to look for and where.

Art, science, and technology again intersected in a presentation of biological data in an artistic experience: ATLAS in Silico is a piece installed at Immersive Visualization Laboratory UC San Diego.

The day concluded with a presentation given by Chris Shaw for Diane Gromala on the uses and experiences of using VR to ameliorate the perception of pain. This was discussed in the context of chronic conditions.

All in all, a varied and interesting day.

\section{Ian E. McDowall Margaret Dolinsky}

